\section{How to stop prednisone in SLE in remission?: Response to: 'Withdrawal of low-dose prednisone in inactive SLE patients: is there another alternative?' by Sabio}

We thank Dr Sabio et al for his interest in our study. ${ }^{12}$ Dr Sabio in his letter suggests that the one-time withdrawal of $5 \mathrm{mg} /$ day of prednisone is too abrupt and could have favoured the appearance of systemic lupus erythematosus (SLE) flares. Dr Sabio describes the practice of his unit which is to decrease by $1.25 \mathrm{mg}$ of prednisone every 2 to 3 months until a complete stop. In the event of a relapse or flare, an effective dose is maintained for a longer period of time and then slowly lowered. The opinion that an abrupt cessation of a very low dose of glucocorticoids (GCs), such as $5 \mathrm{mg}$ of prednisone per day, during a period of remission would be in itself a factor favouring the relapse of SLE and, in consequence, would require a slow and gradual tapering of this treatment is shared by many physicians. However, to our knowledge, no studies to date do support this hypothesis in SLE. In an observational study reporting a gradual GC withdrawal in SLE, about a quarter of the patients relapsed, similar to the number reported in our study. ${ }^{3}$ Furthermore, although one should be careful in drawing a comparison between diseases, it has been reported that continued administration of a very low dose of prednisone or prednisolone to patients with rheumatoid arthritis with a low disease activity status provided better disease control than GC withdrawal, even in case of slow tapering. ${ }^{4}$ It is important to also consider that in our study the vast majority of patients, following the interruption of GC intake, remained on long-term treatment with hydroxychloroquine and thus, indeed, in daily practice SLE treatment is almost never abruptly stopped.

The issue raised by Dr Sabio is of major importance and emphasises that clinicians should in the future (1) determine whether clinical characteristics and biomarkers could help to identify patients with SLE who are at a lower risk of relapse and therefore would benefit from discontinuation of their chronic maintenance treatment and (2) challenge, in academic clinical trials, the modalities of therapeutic de-escalation in patients in remission, in particular in view of the low number of studies that have been reported in this field. ${ }^{6}$ New knowledge on the disease will undoubtedly lead to a better understanding of its treatment. Our study, by concluding that maintenance of $5 \mathrm{mg}$ prednisone is superior to its withdrawal in order to prevent flares in patients with clinically quiescent SLE, provides a rationale that we think paves the way for future studies, aiming to improve patient management.

Alexis Mathian $\odot$, Micheline Pha, Zahir Amoura
Sorbonne Université, Assistance Publique-Hôpitaux de Paris, Groupement Hospitalier Pitié-Salpêtrière, French National Referral Center for Systemic Lupus Erythematosus, Antiphospholipid Antibody Syndrome and Other Autoimmune Disorders, Service de Médecine Interne 2, Institut E3M, Inserm UMRS, Centre d'Immunologie et des Maladies Infectieuses (CIMI-Paris), Paris, France

Correspondence to Dr Alexis Mathian, Internal Medicine, University Hospital Pitié Salpêtrière, Paris 75651, France; alexis.mathian@psl.aphp.fr

Handling editor Josef S Smolen

Contributors AM, MP and ZA wrote the manuscript.

Funding The authors have not declared a specific grant for this research from any funding agency in the public, commercial or not-for-profit sectors.

Competing interests None declared.

Patient and public involvement Patients and/or the public were not involved in the design, or conduct, or reporting, or dissemination plans of this research.

Patient consent for publication Not required.

Provenance and peer review Commissioned; internally peer reviewed.

(C) Author(s) (or their employer(s)) 2020. No commercial re-use. See rights and permissions. Published by BMJ.

\section{Check for updates}

To cite Mathian A, Pha M, Amoura Z. Ann Rheum Dis Epub ahead of print: [please include Day Month Year]. doi:10.1136/annrheumdis-2020-217641

Received 27 April 2020

Accepted 28 April 2020

\section{SLinked}

- https://doi.org/10.1136/annrheumdis-2020-217575

Ann Rheum Dis 2020;0:1. doi:10.1136/annrheumdis-2020-217641

\section{ORCID iD}

Alexis Mathian http://orcid.org/0000-0002-7653-6528

\section{REFERENCES}

1 Sabio JM. Withdrawal of low-dose prednisone in inactive SLE patients: is there another alternative? Ann Rheum Dis 2020. doi:10.1136/annrheumdis-2020-217575. [Epub ahead of print: 27 Apr 2020].

2 Mathian A, Pha M, Haroche J, et al. Withdrawal of low-dose prednisone in SLE patients with a clinically quiescent disease for more than 1 year: a randomised clinical trial. Ann Rheum Dis 2020;79:339-46.

3 Tani C, Elefante E, Signorini V, et al. Glucocorticoid withdrawal in systemic lupus erythematosus: are remission and low disease activity reliable starting points for stopping treatment? A real-life experience. RMD Open 2019;5:e000916.

4 Pincus T, Swearingen CJ, Luta G, et al. Efficacy of prednisone 1-4 mg/day in patients with rheumatoid arthritis: a randomised, double-blind, placebo controlled withdrawal clinical trial. Ann Rheum Dis 2009;68:1715-20.

5 Tengstrand B, Larsson E, Klareskog L, et al. Randomized withdrawal of long-term prednisolone treatment in rheumatoid arthritis: effects on inflammation and bone mineral density. Scand I Rheumatol 2007;36:351-8.

6 Canadian Hydroxychloroquine Study Group. A randomized study of the effect of withdrawing hydroxychloroquine sulfate in systemic lupus erythematosus. N Engl J Med 1991;324:150-4. 